Published in final edited form as:

Org Lett. 2019 May 17; 21(10): 3848-3854. doi:10.1021/acs.orglett.9b01337.

\title{
Synthesis of Alkyl Halides from Aldehydes via Deformylative Halogenation
}

\author{
Shengzong Liang ${ }^{\dagger}$, Tatsuya Kumon ${ }^{\ddagger}$, Ricardo A. Angnes ${ }^{\S}$, Melissa Sanchez" ${ }^{\|}$, Bo Xu $^{\star}{ }^{\star} \perp$, and \\ Gerald B. Hammond ${ }^{*} \dagger$ \\ †Department of Chemistry, University of Louisville, Louisville, Kentucky 40292, United States \\ ‡Faculty of Molecular Chemistry and Engineering, Kyoto Institute of Technology, Matsugasaki, \\ Kyoto 606-8585, Japan \\ §Chemistry Institute, State University of Campinas - Unicamp C.P. 6154, CEP.13083-970, \\ Campinas, São Paulo, Brazil \\ "California State University Fresno, 2555 East San Ramon Avenue M/S SB70, Fresno, California \\ 93740, United States
}

${ }^{\perp}$ Key Laboratory of Science and Technology of Eco-Textiles, Ministry of Education, College of Chemistry, Chemical Engineering and Biotechnology, Donghua University, Shanghai 201620, China

\begin{abstract}
An unprecedented deformylative halogenation of aldehydes to alkyl halides is presented. Under oxidative conditions, 1,4-dihydropyridine (DHP), derived from an aldehyde, generated a C(sp3)radical that coupled with a halogen radical that was generated from inexpensive and atomeconomical halogen sources ( $\mathrm{NaBr}, \mathrm{NaI}$, or $\mathrm{HCl})$, to yield an alkyl halide. Because of the mild conditions, a wide range of functional groups were tolerated, and excellent site selectivity was achieved.
\end{abstract}

\section{Graphical Abstract}

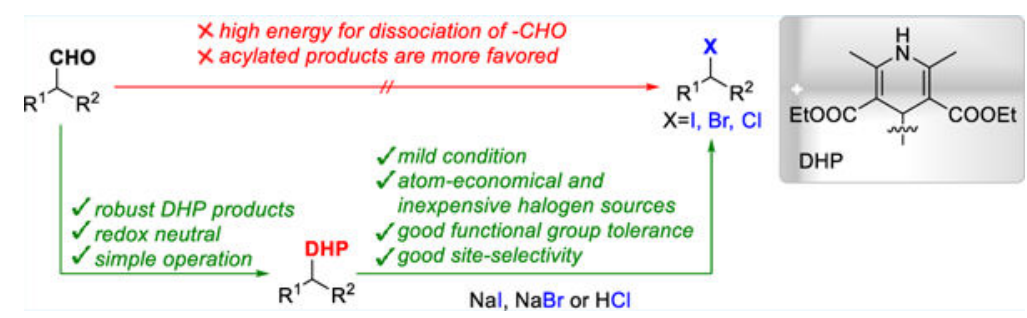

\footnotetext{
*Corresponding Authors bo.xu@dhu.edu.cn., gb.hammond@Louisville.edu. ASSOCIATED CONTENT

Supporting Information

The Supporting Information is available free of charge on the ACS Publications website at DOI: 10.1021/acs.orglett.9b01337.

Experimental detail and copies of NMR spectra (PDF)

The authors declare no competing financial interest.
} 
Halogenated organic compounds are ubiquitous in organic chemistry. ${ }^{1}$ They not only play significant roles as synthetic intermediates and building blocks in organic transformations such as cross-coupling reactions and nucleophilic substitutions, ${ }^{2}$ but they are also versatile precursors for most organometallic species, including Grignard, organozinc, and organocuprate reagents. ${ }^{3}$ Halogenated organic compounds have also been used as essential designer molecules in the pharmaceutical, ${ }^{4}$ agrochemical, ${ }^{5}$ and material science applications. ${ }^{6}$ Their syntheses have been carried out through substitutions, ${ }^{7}$ Markovnikov additions, ${ }^{8}$ and less common radical-based protocols ${ }^{9}$ such as the Hunsdiecker reaction ${ }^{10}$ and its variations. ${ }^{11}$

Recently, the use of visible light as an efficient, clean, and inexpensive energy source for radical-based organic synthesis has received much attention. ${ }^{12}$ However, halogenations using photocatalysis are very rare. ${ }^{13}$ In particular, the chlorination or bromination of arenes was usually restricted to electron-rich substrates, ${ }^{14}$ while the construction of alkyl chloride or bromide faced more challenges such as controlling site selectivity, choice of appropriate substrates, and halogen sources. ${ }^{15}$ Nicewicz and co-workers reported a photocatalyzed antiMarkovnikov hydrochlorination of styrenes. ${ }^{16}$ They utilized the stable benzylic radical to initiate the photoredox reaction and achieve the site-selective installation of chlorine, but only styryl substrates were showcased (Scheme 1a). The Glorius' group reported a Hunsdiecker decarboxylative halogenation strategy using diethyl bromomalonate, NCS, and NIS as halogen sources under photoirradiation (Scheme 1b). ${ }^{17}$ Alexanian and co-workers designed an amide-based halogenating reagent for aliphatic $\mathrm{C}-\mathrm{H}$ halogenation (Scheme 1c). 18

This protocol exhibited predominant $\delta$-selectivity, but the formation of other regioisomers was also observed, in yields ranging from $18 \%$ to $46 \%$. Roizen and co-workers reported a $\gamma$ selective intramolecular chlorination which required prein-stallation of a chlorine-directing group, sulfamate ester (Scheme 1d). ${ }^{19}$

Aldehydes are among the most common functionalities in synthesis, and they are starting materials for a variety of organic transformations, among which deformylative transformation has significant synthetic value because it can integrate one-carbon degradation and further functionalization in a single step. However, such strategies are rare. 20 The reported methods relied on the generation of an acyl radical through hydrogen-atom transfer (HAT), followed by $\mathrm{CO}$ extrusion to form an alkyl radical for further functionalization. But the dissociation of an acyl radical to generate an alkyl radical is a high energy process, and acylated products are more commonly observed. ${ }^{21}$ An alternative is an oxidative process followed by elimination of $\mathrm{CO}_{2}$ to furnish a one-carbon-shorter alkyl radical; ${ }^{22}$ however, the use of strong and stoichiometric oxidants is not desirable in synthesis. Recently, 1,4-dihydropyridines (DHP) easily prepared from aldehydes under neutral redox conditions have been used in deformylative transformations. ${ }^{23}$ Its robustness allows for a wide range of structural derivatizations (see Supporting Information (SI)). Under photoirradiation, DHPs undergo homolysis to generate $\mathrm{C}\left(\mathrm{sp}^{3}\right)$-centered alkyl radicals, which can be employed for further radical coupling reactions. However, these coupling reactions were primarily used in the construction of $\mathrm{C}-\mathrm{C}$ bonds. Herein we report the first photoredox-catalyzed deformylative halogenation strategy to achieve the transformation of 
aldehydes to alkyl halides using readily available, inexpensive, and atom-economical $\mathrm{NaBr}$ and $\mathrm{HCl}$ as halogen sources. In addition, we have successfully developed a photocatalystfree deformylative iodination using $\mathrm{NaI}$ as a halogen source (Scheme 1).

First, we established the conditions for the deformylative bromination using DHP 1a as the substrate (Table 1). After extensive screening, the optimized conditions furnished the desired brominated product $\mathbf{2 a}$ in $98 \%$ yield without the formation of the regioisomer derived from the more stable benzylic radical (Table 1, entry 1). $\mathrm{H}_{2} \mathrm{O}$ was important to dissolve salts and achieve better yields (Table 1, entries 2-3). Other commonly used photocatalysts (B-D) exhibited lower efficacy (Table 1, entries 4-6). The use of organo-oxidants DTBP and TBN or the lack of an oxidant led to poor yields or no reaction (Table 1, entries 7-9). The yield was dramatically decreased when only half the amount of $\mathrm{NaBr}$ was used (Table 1 , entry 10). Both blue LED irradiation and photocatalyst $\mathbf{A}$ were crucial to produce $\mathbf{2 a}$ in higher yields (Table 1, entries 11-13). A low yield was obtained when this reaction was conducted under air (Table 1, entry 14).

With the optimized conditions established, we proceeded to evaluate the scope of the deformylative bromination process. As shown in Scheme 2, a myriad of DHPs were suitable substrates, giving the corresponding brominated products in good to excellent yields. Notably, no regioisomeric products were observed even when active benzylic positions were available (2a-2c). A diverse range of functional groups were well tolerated, such as hydroxyl, ether, ester, ketone, aldehyde, thioether, nitro, and nitrile groups (2d-2m). Heterocyclic compounds such as furan (2n), thiophene (2o), thiazole (2p), benzotriazole (2q), indole (2r), and $N$-Boc-piperidine (2s) were suitable substrates. Benzylic DHPs also succeeded in delivering the brominated products in good yields $(\mathbf{2 t}-\mathbf{2 x})$.

Once the versatility of the deformylative bromination was demonstrated, we focused our attention on deformylative chlorination. Our newly developed HCl/DMPU ${ }^{24,8 b}$ was superior to other inorganic chloride salts (Table 2, entries 1-7), while $\operatorname{Ir}(\mathrm{ppy})_{3}(\mathbf{B})$ was a more efficient photocatalyst (Table 2, entries 7-9). Both light and photocatalyst were crucial in the production of $\mathbf{3 a}$ (Table 2, entries 10-11). With these modified conditions in hand, we examined the scope of the deformylative chlorination protocol. As illustrated in Scheme 3, our method produced the corresponding chlorinated products in good to excellent yields. Various functional groups (3a-3p) as well as heterocyclic arenes $(\mathbf{3 q}-\mathbf{3 t})$ were tolerated.

The scalability of our deformylative halogenation was evaluated using $3 \mathrm{mmol}$ of DHP substrate 1a. The halogenated products were generated in yields of $79 \%$ and $67 \%$, respectively (Figure 1a). To highlight the excellent site selectivity of this protocol, two similar but distinguishable DHPs (1x and $\mathbf{1 y})$ were prepared and subjected under the standard conditions to both parallel and crossover experiments (Figure 1b). In the former, only in situ DHP-substituted products were observed, while, in the latter, two brominated products ( $2 \mathbf{y}$ and $\mathbf{2 z}$ ) were formed with the same mole ratio as the starting DHPs, indicating that the reactivities of $\mathbf{1 x}$ and $\mathbf{1 y}$ were the same and that no isomerization occurred during this reaction. 
To gain insight into the reaction mechanism, the bromination of 1a was monitored with the light on/off over time. A smooth transformation under irradiation by blue LEDs and no further production of $\mathbf{2 a}$ in the dark suggested that the reaction proceeded through a photoredox catalytic pathway rather than a radical chain pathway (Figure 1c). A radical quenching experiment was also conducted by adding the radical scavenger 2,2,6,6tetramethylpiperidine-1-oxyl (TEMPO) to the reaction of 1a. We observed that the bromination was completely inhibited (Figure 1d). Based on the above observations, we proposed a plausible mechanism for this bromination process, shown in Scheme 4a. Upon visible light irradiation the excited photocatalyst $* \mathrm{Ru}(\text { bpy })_{3}{ }^{2+}$ is oxidized by $\mathrm{K}_{2} \mathrm{~S}_{2} \mathrm{O}_{8}$ $\left(E_{\mathrm{red}}\left(\mathrm{S}_{2} \mathrm{O}_{8}{ }^{2-} / \mathrm{SO}_{4}{ }^{2-}\right)=+2.01 \mathrm{~V} \text { vs SCE}\right)^{25}$ through single electron transfer (SET), resulting in the formation of $\mathrm{SO}_{4}{ }^{2-}, \mathrm{SO}_{4}{ }^{-}$, and a strong oxidative $\mathrm{Ru}(\mathrm{bpy})_{3}{ }^{3+}\left(E_{\mathrm{red}}{ }^{\mathrm{III} / \mathrm{II}}=+1.29 \mathrm{~V}\right.$ vs SCE) species. ${ }^{120}$ Then the single-electron oxidization of DHP $1\left(E_{\mathrm{red}}=+1.03 \mathrm{~V}\right.$ vs $\mathrm{SCE})^{26,23 \mathrm{~g}}$ yields radical II and reductively quench the photocatalyst. The resulting radical II then fragments to an alkyl radical IV along with pyridine derivative III, driven by aromatization. The high reduction potential of the generated $\mathrm{SO}^{\bullet-}\left(E\left(\mathrm{SO}^{\bullet-} / \mathrm{SO}_{4}\right)=+2.6\right.$ $\mathrm{V}$ vs SCE) enables the further oxidization of $\mathrm{Br}^{-}\left(E_{\mathrm{red}}\left(\mathrm{Br}^{\bullet} / \mathrm{Br}^{-}=+0.8 \mathrm{~V} \text { vs SCE}\right)^{27}\right.$ to its radical form, thus rendering the radical coupling with alkyl radical IV to furnish the brominated product 2 . In the chlorination process, however, the single electron transfer (SET) from the ground state of DHP $1\left(E_{\mathrm{red}}=+1.03 \mathrm{~V} \text { vs SCE}\right)^{26,23 \mathrm{~g}}$ to either the photoexcited Ir(III) $\left(E_{\text {red }}{ }^{* I I I / I I}=+0.31 \mathrm{~V} \text { vs SCE }\right)^{120}$ or the oxidized $\operatorname{Ir}(\mathrm{IV})\left(E_{\mathrm{red}} \mathrm{IV} / \mathrm{III}=\right.$ $+0.77 \mathrm{~V}$ vs SCE$)^{120}$ is not favored. Therefore, the possibility of generating radical $\mathbf{V}$ via photo-excited DHP 1* was suggested, which has been experimentally proved. ${ }^{23 \mathrm{f}}$ This different radical initiation is also evident by the formation of the chlorinated product in moderate yield when only the blue LED was employed (Table 2, entry 10). The radical $\mathbf{V}$ would reductively quench the oxidized photocatalyst $\operatorname{Ir}(\mathrm{IV})$ to form the pyridine derivative III. The resulting alkyl radical IV would follow a similar radical coupling route as the bromination, giving rise to chlorinated product 3 (Scheme $4 \mathrm{~b}$ ).

Subsequently, we examined the deformylative iodination using $\mathrm{NaI}$ as a halogen source.

Unlike in the case of bromination and chlorination, a photoredox catalyst was not required in this protocol because a iodine radical is generated from the $\mathrm{NaI} / \mathrm{K}_{2} \mathrm{~S}_{2} \mathrm{O}_{8}$ system. ${ }^{28}$ After extensive optimization (see SI), we found that $95 \%$ of the product could be obtained in the presence of 1.5 equiv each of $\mathrm{NaI} / \mathrm{K}_{2} \mathrm{~S}_{2} \mathrm{O}_{8}$. As shown in Scheme 5, various DHPs were suitable substrates, giving the desired iodinated products in good to excellent yields $(\mathbf{4 a}-\mathbf{4 I})$ although benzylic DHP 4m showed less reactivity.

In conclusion, we have developed a highly efficient visible-light-mediated deformylative halogenation protocol using inexpensive and atom-economical halogen sources. This protocol exhibited excellent site selectivity and functional group tolerance, which are highly desired in late-stage functionalization.

\section{Supplementary Material}

Refer to Web version on PubMed Central for supplementary material. 


\section{ACKNOWLEDGMENTS}

We are grateful to the National Institutes of Health for financial support (R01GM121660). B.X. is grateful to the National Science Foundation of China for financial support (NSFC-21672035). R.A.A. thanks FAPESP for Grant 2017/ 01779-2.

\section{REFERENCES}

(1). Petrone DA; Ye J; Lautens M Modern Transition-Metal-Catalyzed Carbon-Halogen Bond Formation. Chem. Rev 2016, 116, 8003-8104. [PubMed: 27341176]

(2). (a)Frisch AC; Beller M Catalysts for Cross-Coupling Reactions with Non-activated Alkyl Halides. Angew. Chem., Int. Ed 2005, 44, 674-688.(b)Kambe N; Iwasaki T; Terao J Pd-catalyzed crosscoupling reactions of alkyl halides. Chem. Soc. Rev 2011, 40, 4937-4947. [PubMed: 21785791] (c)Littke AF; Fu GC Palladium-Catalyzed Coupling Reactions of Aryl Chlorides. Angew. Chem., Int. Ed 2002, 41, 4176-4211.(d)Rudolph A; Lautens M Secondary Alkyl Halides in TransitionMetal-Catalyzed Cross-Coupling Reactions. Angew. Chem., Int. Ed 2009, 48, 2656-2670. (e)Tasker SZ; Standley EA; Jamison TF Recent advances in homogeneous nickel catalysis. Nature 2014, 509, 299. [PubMed: 24828188] (f)Terao J; Kambe N Cross-Coupling Reaction of Alkyl Halides with Grignard Reagents Catalyzed by Ni, Pd, or Cu Complexes with $\pi$-Carbon Ligand(s). Acc. Chem. Res 2008, 41, 1545-1554. [PubMed: 18973349]

(3). (a)Boudier A; Bromm LO; Lotz M; Knochel P New Applications of Polyfunctional Organometallic Compounds in Organic Synthesis. Angew. Chem., Int. Ed 2000, 39, 4414-4435. (b)Kim JH; Ko YO; Bouffard J; Lee S.-g. Advances in tandem reactions with organozinc reagents. Chem. Soc. Rev 2015, 44, 2489-2507. [PubMed: 25708795] (c)Sun C-L; Shi Z-J Transition-Metal-Free Coupling Reactions. Chem. Rev 2014, 114, 9219-9280. [PubMed: 25184859]

(4). (a)Hernandes M; Cavalcanti SM; Moreira DR; de Azevedo W Jr.; Leite AC Halogen Atoms in the Modern Medicinal Chemistry: Hints for the Drug Design. Curr. Drug Targets 2010, 11, 303-314. [PubMed: 20210755] (b)Wilcken R; Zimmermann MO; Lange A; Joerger AC; Boeckler FM Principles and Applications of Halogen Bonding in Medicinal Chemistry and Chemical Biology. J. Med. Chem 2013, 56, 1363-1388. [PubMed: 23145854]

(5). Jeschke $P$ The unique role of halogen substituents in the design of modern agrochemicals. Pest Manage. Sci 2010, 66, 10-27.

(6). (a)Amanchukwu CV; Harding JR; Shao-Horn Y; Hammond PT Understanding the Chemical Stability of Polymers for Lithium-Air Batteries. Chem. Mater 2015, 27, 550-561.(b)Tang ML; Bao Z Halogenated Materials as Organic Semiconductors. Chem. Mater 2011, 23, 446-455.

(7). (a)Huy PH; Motsch S; Kappler SM Formamides as Lewis Base Catalysts in SN Reactions Efficient Transformation of Alcohols into Chlorides, Amines, and Ethers. Angew. Chem., Int. Ed 2016, 55, 10145-10149.(b)Munyemana F; George I; Devos A; Colens A; Badarau E; FrisqueHesbain A-M; Loudet A; Differding E; Damien J-M; Remíion J; Van Uytbergen J; Ghosez L A mild method for the replacement of a hydroxyl group by halogen. 1. Scope and chemoselectivity. Tetrahedron 2016, 72, 420-430.(c)Senaratne PA; Orihuela FM; Malcolm AJ; Anderson KG Recyclable Lucas Reagent in Converting Aliphatic Alcohols to Chlorides1. Org. Process Res. Dev 2003, 7, 185-186.

(8). (a)Kropp PJ; Daus KA; Tubergen MW; Kepler KD; Wilson VP; Craig SL; Baillargeon MM; Breton GW Surface-mediated reactions. 3. Hydrohalogenation of alkenes. J. Am. Chem. Soc 1993, 115, 3071-3079.(b)Liang S; Hammond GB; Xu B Metal-free regioselective hydrochlorination of unactivated alkenes via a combined acid catalytic system. Green Chem 2018, 20, 680-684. [PubMed: 29750081] (c)Schevenels FT; Shen M; Snyder SA Isolable and Readily Handled Halophosphonium Pre-reagents for Hydro-and Deuter-iohalogenation. J. Am. Chem. Soc 2017, 139, 6329-6337. [PubMed: 28462991] (d)Yadav VK; Babu KG A Remarkably Efficient Markovnikov Hydro-chlorination of Olefins and Transformation of Nitriles into Imidates by Use of AcCl and an Alcohol. Eur. J. Org. Chem 2005, 2005, 452-456.

(9). (a)Gaspar B; Carreira EM Catalytic Hydrochlorination of Unactivated Olefins with paraToluenesulfonyl Chloride. Angew. Chem., Int. Ed 2008, 47, 5758-5760.(b)Liu W; Groves JT Manganese Porphyrins Catalyze Selective C-H Bond Halogenations. J. Am. Chem. Soc 2010, 
132, 12847-12849. [PubMed: 20806921] (c)Podgorsěk A; Zupan M; Iskra J Oxidative Halogenation with "Green" Oxidants: Oxygen and Hydrogen Peroxide. Angew. Chem., Int. Ed 2009, 48, 8424-8450.

(10). (a)Hunsdiecker H; Hunsdiecker C Über den Abbau der Salze aliphatischer Saüren durch Brom. Ber. Dtsch. Chem. Ges. B 1942, 75, 291-297.(b)Das PJ; Roy S Catalytic Hunsdiecker Reaction of $a, \beta$-Unsatuated Carboxylic Acids: How Efficient Is the Catalyst? J. Org. Chem 2002, 67, 7861-7864. [PubMed: 12398515]

(11). (a)Barton DHR; Crich D; Motherwell WB A practical alternative to the hunsdiecker reaction. Tetrahedron Lett 1983, 24, 4979-4982.(b)Camps P; Lukach AE; Pujol X; Vaźquez S Hunsdiecker-Type Bromodecarboxylation of Carboxylic Acids with Iodosobenzene DiacetateBromine. Tetrahedron 2000, 56, 2703-2707.(c)Cristol S; Firth W Jr. Communications. A Convenient Synthesis of Alkyl Halides from Carboxylic Acids. J. Org. Chem 1961, 26, 280-280. (d)Kochi JKA New Method for Halodecarbox-ylation of Acids Using Lead(IV) Acetate. J. Am. Chem. Soc 1965, 87, 2500-2502.(e)McKillop A; Bromley D; Taylor EC Thallium in organic synthesis. VI. Synthesis of primary aliphatic bromides. J. Org. Chem 1969, 34, 1172-1173.(f)Tan X; Song T; Wang Z; Chen H; Cui L; Li C Silver-Catalyzed Decarboxylative Bromination of Aliphatic Carboxylic Acids. Org. Lett 2017, 19, 1634-1637. [PubMed: 28286955] (g)Wang Z; Zhu L; Yin F; Su Z; Li Z; Li C Silver-Catalyzed Decarboxylative Chlorination of Aliphatic Carboxylic Acids. J. Am. Chem. Soc 2012, 134, 4258-4263. [PubMed: 22316183]

(12). (a)Arora A; Weaver JD Visible Light Photocatalysis for the Generation and Use of Reactive Azolyl and Polyfluoroaryl Intermediates. Acc. Chem. Res 2016, 49, 2273-2283. [PubMed: 27682342] (b)Chatterjee T; Iqbal N; You Y; Cho EJ Controlled Fluoroalkylation Reactions by Visible-Light Photoredox Catalysis. Acc. Chem. Res 2016, 49, 2284-2294. [PubMed: 27626105] (c)Chen J-R; Hu X-Q; Lu L-Q; Xiao W-J Visible light photoredox-controlled reactions of Nradicals and radical ions. Chem. Soc. Rev 2016, 45, 2044-2056. [PubMed: 26839142] (d)Fabry DC; Rueping M Merging Visible Light Photoredox Catalysis with Metal Catalyzed C-H Activations: On the Role of Oxygen and Superoxide Ions as Oxidants. Acc. Chem. Res 2016, 49, 1969-1979. [PubMed: 27556812] (e)Ghosh I; Marzo L; Das A; Shaikh R; König B Visible Light Mediated Photoredox Catalytic Arylation Reactions. Acc. Chem. Res 2016, 49, 1566-1577. [PubMed: 27482835] (f)Hopkinson MN; Tlahuext-Aca A; Glorius F Merging Visible Light Photoredox and Gold Catalysis. Acc. Chem. Res 2016, 49, 2261-2272. [PubMed: 27610939] (g)Jin Y; Fu H Visible-Light Photoredox Decarboxylative Couplings. Asian J. Org. Chem 2017, 6, 368-385.(h)Kärkäs MD Photochemical Generation of Nitrogen-Centered Amidyl, Hydrazonyl, and Imidyl Radicals: Methodology Developments and Catalytic Applications. ACS Catal 2017, 7, 4999-5022.(i)Koike T; Akita M A versatile strategy for difunctionalization of carbon-carbon multiple bonds by photoredox catalysis. Org. Chem. Front 2016, 3, 1345-1349.(j)König B Photocatalysis in Organic Synthesis - Past, Present, and Future. Eur. J. Org. Chem 2017, 2017, 1979-1981.(k)Lee KN; Ngai M-Y Recent developments in transition-metal photoredox-catalysed reactions of carbonyl derivatives. Chem. Commun 2017, 53, 13093-13112.(1)Matsui JK; Lang SB; Heitz DR; Molander GA Photoredox-Mediated Routes to Radicals: The Value of Catalytic Radical Generation in Synthetic Methods Development. ACS Catal 2017, 7, 2563-2575. [PubMed: 28413692] (m)Morris SA; Wang J; Zheng N The Prowess of Photogenerated Amine Radical Cations in Cascade Reactions: From Carbocycles to Heterocycles. Acc. Chem. Res 2016, 49, 1957-1968. [PubMed: 27536956] (n)Narayanam JMR; Stephenson CRJ Visible light photoredox catalysis: applications in organic synthesis. Chem. Soc. Rev 2011, 40, 102-113. [PubMed: 20532341] (o)Prier CK; Rankic DA; MacMillan DWC Visible Light Photoredox Catalysis with Transition Metal Complexes: Applications in Organic Synthesis. Chem. Rev 2013, 113, 5322- 5363. [PubMed: 23509883] (p)Romero NA; Nicewicz DA Organic Photoredox Catalysis. Chem. Rev 2016, 116, 10075-10166. [PubMed: 27285582] (q)Roslin S; Odell LR Visible-Light Photocatalysis as an Enabling Tool for the Functionalization of Unactivated C(sp3)-Substrates. Eur. J. Org. Chem 2017, 2017, 1993-2007.(r)Skubi KL; Blum TR; Yoon TP Dual Catalysis Strategies in Photochemical Synthesis. Chem. Rev 2016, 116, 10035-10074. [PubMed: 27109441] (s)Srivastava V; Singh PP Eosin Y catalysed photoredox synthesis: a review. RSC Adv 2017, 7, 31377-31392.(t)Tellis JC; Kelly CB; Primer DN; Jouffroy M; Patel NR; Molander GA Single-Electron Transmetalation via Photoredox/Nickel Dual Catalysis: Unlocking a New Paradigm for sp3-sp2 Cross-Coupling. Acc. Chem. Res 2016, 49, 1429-1439. [PubMed: 27379472] (u)Twilton J; Le C; Zhang P; Shaw MH; Evans RW; MacMillan DWC The 
merger of transition metal and photocatalysis. Nat. Rev. Chem 2017, 1, 0052.(v)Xuan J; Xiao WJ Visible-Light Photoredox Catalysis. Angew. Chem., Int. Ed 2012, 51, 6828-6838.

(13). (a)Cantillo D; de Frutos O; Rincon JA; Mateos C; Kappe CO A Scalable Procedure for LightInduced Benzylic Brominations in Continuous Flow. J. Org. Chem 2014, 79, 223-229. [PubMed: 24261546] (b)Kim HJ; Kim M Visible Light-Mediated Installation of Halogen Functionalities into Multiple Bond Systems. ChemistrySelect 2017, 2, 9136-9146.(c)Tu H; Zhu S; Qing F-L; Chu L Visible-light-induced halogenation of aliphatic CH bonds. Tetrahedron Lett 2018, 59, 173-179.

(14). (a)Hering T; König B Photocatalytic activation of N-chloro compounds for the chlorination of arenes. Tetrahedron 2016, 72, 7821-7825.(b)Hering T; Mühldorf B; Wolf R; König B Halogenase-Inspired Oxidative Chlorination Using Flavin Photo-catalysis. Angew. Chem., Int. Ed 2016, 55, 5342-5345.(c)Kawakami K; Tsuda A Brominated Methanes as Photoresponsive Molecular Storage of Elemental Br2. Chem. - Asian J 2012, 7, 2240-2252. [PubMed: 22711295] (d)Li R; Wang ZJ; Wang L; Ma BC; Ghasimi S; Lu H; Landfester K; Zhang KAI Photocatalytic Selective Bromination of Electron-Rich Aromatic Compounds Using Microporous Organic Polymers with Visible Light. ACS Catal 2016, 6, 1113-1121.(e)Ohkubo K; Mizushima K; Fukuzumi S Oxygenation and chlorination of aromatic hydrocarbons with hydrochloric acid photosensitized by 9-mesityl-10-methylacridinium under visible light irradiation. Res. Chem. Intermed 2013, 39, 205-220.(f)Ohkubo K; Mizushima K; Iwata R; Fukuzumi S Selective photocatalytic aerobic bromination with hydrogen bromidevia an electron-transfer state of 9mesityl-10-methylacridinium ion. Chem. Sci 2011, 2, 715-722.(g)Petzold D; König B Photocatalytic Oxidative Bromination of Electron-Rich Arenes and Heteroarenes by Anthraquinone. Adv. Synth. Catal 2018, 360, 626-630.(h)Zhang L; Hu X Room temperature C(sp2)-H oxidative chlorination via photoredox catalysis. Chem. Sci 2017, 8, 7009-7013. [PubMed: 29147528]

(15). (a)Cristol SJ; Seapy DG New procedure for the transformation of alcohols to alkyl halides via xanthate esters and free-radical intermediates. J. Org. Chem 1982, 47, 132-136.(b)Griffin JD; Cavanaugh CL; Nicewicz DA Reversing the Regioselectivity of Halofunctionalization Reactions through Cooperative Photoredox and Copper Catalysis. Angew. Chem., Int. Ed 2017, 56, $2097-$ 2100.(c)Han L; Xia J-B; You L; Chen C Ketone-catalyzed photochemical C(sp3)-H chlorination. Tetrahedron 2017, 73, 3696-3701. [PubMed: 28717256] (d)Kee CW; Chan KM; Wong MW; Tan C-H Selective Bromination of sp3 C-H Bonds by Organophotoredox Catalysis. Asian J. Org. Chem 2014, 3, 536-544.(e)Manabe Y; Kitawaki Y; Nagasaki M; Fukase K; Matsubara H; Hino Y; Fukuyama T; Ryu I Revisiting the Bromination of C-H Bonds with Molecular Bromine by Using a Photo-Microflow System. Chem. - Eur. J 2014, 20, 12750-12753. [PubMed: 25170976] (f)Nishina Y; Ohtani B; Kikushima K Bromination of hydrocarbons with $\mathrm{CBr} 4$, initiated by lightemitting diode irradiation. Beilstein J. Org. Chem 2013, 9, 1663-1667. [PubMed: 24062826] (g)Qin Q; Yu S Visible-Light-Promoted Remote C(sp3)-H Amidation and Chlorination. Org. Lett 2015, 17, 1894-1897. [PubMed: 25853884] (h)Shibatomi K; Kitahara K; Sasaki N; Kawasaki Y; Fujisawa I; Iwasa S Enantioselective decarboxylative chlorination of $\beta$ ketocarboxylic acids. Nat. Commun 2017, 8, 15600. [PubMed: 28580951] (i)Su JY; Grünenfelder DC; Takeuchi K; Reisman SE Radical Deoxychlorination of Cesium Oxalates for the Synthesis of Alkyl Chlorides. Org. Lett 2018, 20, 4912-4916. [PubMed: 30062894] (j)Wang Y; Li G-X; Yang G; He G; Chen G A visible-light-promoted radical reaction system for azidation and halogenation of tertiary aliphatic C-H bonds. Chem. Sci 2016, 7, 2679-2683. [PubMed: 28660040] (k)Zhao M; Lu W Visible Light-Induced Oxidative Chlorination of Alkyl sp3 C-H Bonds with NaCl/Oxone at Room Temperature. Org. Lett 2017, 19, 4560-4563. [PubMed: 28817287] (1)Zhao M; Lu W Catalytic Bromination of Alkyl sp3C-H Bonds with KBr/Air under Visible Light. Org. Lett 2018, 20, 5264-5267. [PubMed: 30133295]

(16). Wilger DJ; Grandjean J-MM; Lammert TR; Nicewicz DA The direct anti-Markovnikov addition of mineral acids to styrenes. Nat. Chem 2014, 6, 720. [PubMed: 25054943]

(17). Candish L; Standley EA; Gomez-Suaŕez A; Mukherjee S; Glorius F Catalytic Access to Alkyl Bromides, Chlorides and Iodides via Visible Light-Promoted Decarboxylative Halogenation. Chem. - Eur. J 2016, 22, 9971-9974. [PubMed: 27191347]

(18). (a)Quinn RK; Könst ZA; Michalak SE; Schmidt Y; Szklarski AR; Flores AR; Nam S; Horne DA; Vanderwal CD; Alexanian EJ Site-Selective Aliphatic C-H Chlorination Using N-Chloroamides 
Enables a Synthesis of Chlorolissoclimide. J. Am. Chem. Soc 2016, 138, 696-702. [PubMed: 26694767] (b)Schmidt VA; Quinn RK; Brusoe AT; Alexanian EJ Site-Selective Aliphatic C-H Bromination Using N-Bromoamides and Visible Light. J. Am. Chem. Soc 2014, 136, 1438914392. [PubMed: 25232995]

(19). Short MA; Blackburn JM; Roizen JL Sulfamate Esters Guide Selective Radical-Mediated Chlorination of Aliphatic C-H Bonds. Angew. Chem., Int. Ed 2018, 57, 296-299.

(20). (a)Guo X; Wang J; Li C-J An Olefination via Ruthenium-Catalyzed Decarbonylative Addition of Aldehydes to Terminal Alkynes. J. Am. Chem. Soc 2009, 131, 15092-15093. [PubMed: 19919154] (b)Harris EFP; Waters WA Thiol Catalysis of the Homolytic Decomposition of Aldehydes. Nature 1952, 170, 212.(c)Jung Y; Kim I Deformylative Intramolecular Hydroarylation: Synthesis of Benzo[e]-pyrido[1,2-a]indoles. Org. Lett 2015, 17, 4600-4603. [PubMed: 26345614] (d)Patra T; Manna S; Maiti D Metal-Mediated Deformylation Reactions: Synthetic and Biological Avenues. Angew. Chem., Int. Ed 2011, 50, 12140-12142.(e)Paul S; Guin J Dioxygen-Mediated Decarbon-ylative C-H Alkylation of Heteroaromatic Bases with Aldehydes. Chem. - Eur. J 2015, 21, 17618-17622. [PubMed: 26493363] (f)Shuai Q; Yang L; Guo X; Baslé O; Li C-J Rhodium-Catalyzed Oxidative C-H Arylation of 2-Arylpyridine Derivatives via Decarbonylation of Aromatic Aldehydes. J. Am. Chem. Soc 2010, 132, 1221212213. [PubMed: 20712314] (g)Tang R-J; He Q; Yang L Metal-free oxidative decarbonylative coupling of aromatic aldehydes with arenes: direct access to biaryls. Chem. Commun 2015, 51, 5925-5928.

(21). (a)Chatgilialoglu C; Crich D; Komatsu M; Ryu I Chemistry of Acyl Radicals. Chem. Rev 1999, 99, 1991-2070. [PubMed: 11849018] (b)Esposti S; Dondi D; Fagnoni M; Albini A Acylation of Electrophilic Olefins through Decatungstate-Photocatalyzed Activation of Aldehydes. Angew. Chem., Int. Ed 2007, 46, 2531-2534.(c)Matcha K; Antonchick AP Metal-Free CrossDehydrogenative Coupling of Heterocycles with Aldehydes. Angew. Chem., Int. Ed 2013, 52, 2082-2086.(d)Mukherjee S; Patra T; Glorius F Cooperative Catalysis: A Strategy To Synthesize Trifluoromethyl-thioesters from Aldehydes. ACS Catal 2018, 8, 5842-5846.(e)Tsujimoto S; Iwahama T; Sakaguchi S; Ishii Y The radical-chain addition of aldehydes to alkenes by the use of N-hydroxyphthalimide (NHPI) as a polarity-reversal catalyst. Chem. Commun 2001, 2352-2353. (f) Yi H; Zhang G; Wang H; Huang Z; Wang J; Singh AK; Lei A Recent Advances in Radical CH Activation/Radical Cross-Coupling. Chem. Rev 2017, 117, 9016-9085. [PubMed: 28639787] (g)Zhang X; MacMillan DWC Direct Aldehyde C-H Arylation and Alkylation via the Combination of Nickel, Hydrogen Atom Transfer, and Photoredox Catalysis. J. Am. Chem. Soc 2017, 139, 11353-11356. [PubMed: 28780856]

(22). (a)Ellington BR; Paul B; Das D; Vitek AK; Zimmerman PM; Marsh ENG An Unusual IronDependent Oxidative Deformylation Reaction Providing Insight into Hydrocarbon Biosynthesis in Nature. ACS Catal 2016, 6, 3293-3300.(b)Shokri A; Que L Conversion of Aldehyde to Alkane by a Peroxoiron(III) Complex: A Functional Model for the Cyanobacterial AldehydeDeformylating Oxygenase. J. Am. Chem. Soc 2015, 137, 7686-7691. [PubMed: 26030345] (c)Watanabe E; Kaiho A; Kusama H; Iwasawa N Cobalt-Salen Complex-Catalyzed Oxidative Generation of Alkyl Radicals from Aldehydes for the Preparation of Hydroperoxides. J. Am. Chem. Soc 2013, 135, 11744-11747. [PubMed: 23915227]

(23). (a)Badir SO; Dumoulin A; Matsui JK; Molander GA Synthesis of Reversed C-Acyl Glycosides through Ni/Photoredox Dual Catalysis. Angew. Chem., Int. Ed 2018, 57, 6610-6613.(b)Buzzetti L; Prieto A; Roy SR; Melchiorre P Radical-Based C-C Bond-Forming Processes Enabled by the Photoexcitation of 4-Alkyl-1,4-dihydropyridines. Angew. Chem., Int. Ed 2017, 56, 15039-15043. (c)Chen W; Liu Z; Tian J; Li J; Ma J; Cheng X; Li G Building Congested Ketone: Substituted Hantzsch Ester and Nitrile as Alkylation Reagents in Photoredox Catalysis. J. Am. Chem. Soc 2016, 138, 12312-12315. [PubMed: 27622653] (d)de Assis FF; Huang X; Akiyama M; Pilli RA; Meggers E Visible-Light-Activated Catalytic Enantioselective $\beta$-Alkylation of $a$, $\beta$-Unsaturated 2-Acyl Imidazoles Using Hantzsch Esters as Radical Reservoirs. J. Org. Chem 2018, 83, 10922 10932. [PubMed: 30028138] (e)Dumoulin A; Matsui JK; Gutieŕrez-Bonet Á; Molander GA Synthesis of Non-Classical Arylated C-Saccharides through Nickel/Photoredox Dual Catalysis. Angew. Chem., Int. Ed 2018, 57, 6614-6618.(f)Gu F; Huang W; Liu X; Chen W; Cheng X Substituted Hantzsch Esters as Versatile Radical Reservoirs in Photoredox Reactions. Adv. Synth. Catal 2018, 360, 925-931.(g)Gutieŕrez-Bonet Á; Tellis JC; Matsui JK; Vara BA; 
Molander GA 1,4-Dihydropyridines as Alkyl Radical Precursors: Introducing the Aldehyde Feedstock to Nickel/Photoredox Dual Catalysis. ACS Catal 2016, 6, 8004-8008. [PubMed: 27990318] (h)Li G; Chen R; Wu L; Fu Q; Zhang X; Tang Z Alkyl Transfer from C-C Cleavage. Angew. Chem., Int. Ed 2013, 52, 8432-8436.(i)Nakajima K; Nojima S; Nishibayashi Y Nickeland Photoredox-Catalyzed Cross-Coupling Reactions of Aryl Halides with 4-Alkyl-1,4dihydropyridines as Formal Nucleophilic Alkylation Reagents. Angew. Chem., Int. Ed 2016, 55, 14106-14110.(j)Verrier C; Alandini N; Pezzetta C; Moliterno M; Buzzetti L; Hepburn HB; VegaPeñaloza A; Silvi M; Melchiorre P. Direct Stereoselective Installation of Alkyl Fragments at the $\beta$-Carbon of Enals via Excited Iminium Ion Catalysis. ACS Catal 2018, 8, 1062-1066.(k)Zhang $\mathrm{H}-\mathrm{H}$; Yu S Radical Alkylation of Imines with 4-Alkyl-1,4-dihydropyridines Enabled by Photoredox/Brønsted Acid Cocatalysis. J. Org. Chem 2017, 82, 9995-10006. [PubMed: 28825289]

(24). (a)Ebule R; Liang S; Hammond GB; Xu B Chloride-Tolerant Gold(I)-Catalyzed Regioselective Hydrochlorination of Alkynes. ACS Catal 2017, 7, 6798-6801. [PubMed: 29034119] (b)Liang S; Ebule R; Hammond GB; Xu B A Chlorinating Reagent Yields Vinyl Chlorides with High Regioselectivity under Heterogeneous Gold Catalysis. Org. Lett 2017, 19, 4524-4527. [PubMed: 28809497]

(25). (a)Gutieŕrez-Bonet Á;Remeur C; Matsui JK; Molander GA Late-Stage C-H Alkylation of Heterocycles and 1,4-Quinones via Oxidative Homolysis of 1,4-Dihydropyridines. J. Am. Chem. Soc 2017, 139, 12251-12258. [PubMed: 28832137] (b)Schweizer S; Tresse C; Bisseret P; Laleveé J; Evano G; Blanchard N. Stereodivergent Hydro-germylations of $a$-Trifluoromethylated Alkynes and Their Applications in Cross-Coupling Reactions. Org. Lett 2015, 17, 1794-1797. [PubMed: 25811960]

(26). Cheng J-P; Lu Y; Zhu X-Q; Sun Y; Bi F; He J Heterolytic and Homolytic N-H Bond Dissociation Energies of 4-Substituted Hantzsch 2,6-Dimethyl-1,4-dihydropyridines and the Effect of One-Electron Transfer on the N-H Bond Activation. J. Org. Chem 2000, 65, 38533857. [PubMed: 10864775]

(27). Zhang P; Le CC; MacMillan DWC Silyl Radical Activation of Alkyl Halides in Metallaphotoredox Catalysis: A Unique Pathway for Cross-Electrophile Coupling. J. Am. Chem. Soc 2016, 138, 8084-8087. [PubMed: 27263662]

(28). (a)Semwal R; Ravi C; Kumar R; Meena R; Adimurthy S Sodium Salts ( $\mathrm{NaI} / \mathrm{NaBr} / \mathrm{NaCl})$ for the Halogenation of Imidazo-Fused Heterocycles. J. Org. Chem 2019, 84, 792-805. [PubMed: 30561207] (b)Tonnar J; Lacroix-Desmazes DP Use of Sodium Iodide as the Precursor to the Control Agent in Ab Initio Emulsion Polymerization. Angew. Chem., Int. Ed 2008, 47, 1294 1297. 
a)<smiles>CC(P)Cc1ccc(C(C)(C)C)cc1</smiles>

c)

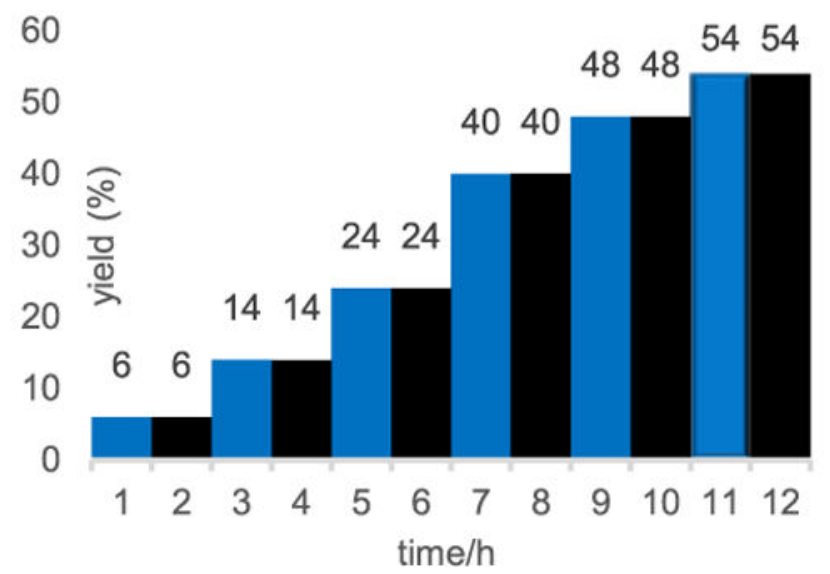
condition

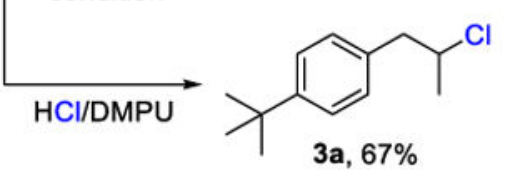

b) parallel experiment
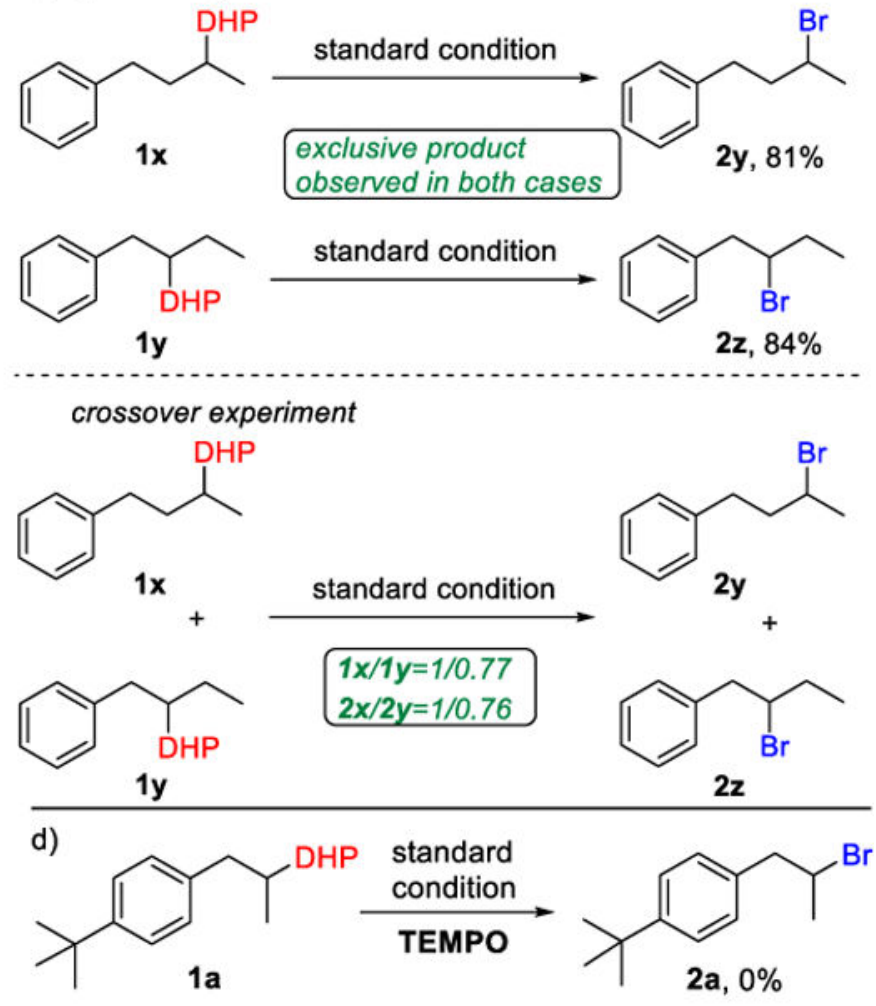

Figure 1.

(a) Gram-scale synthesis; (b) Light on/off experiment; (c) Selectivity study; (d) Radical quenching experiment. 
a) anti-Markovnikov hydrochlorination of styrene

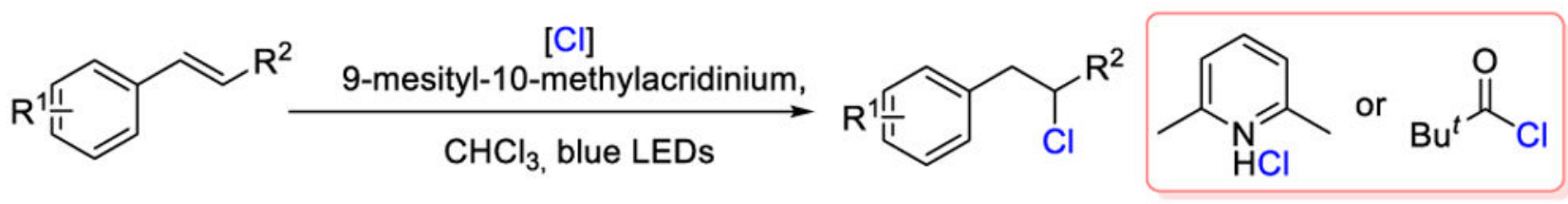

b) Decarboxylative halogenation
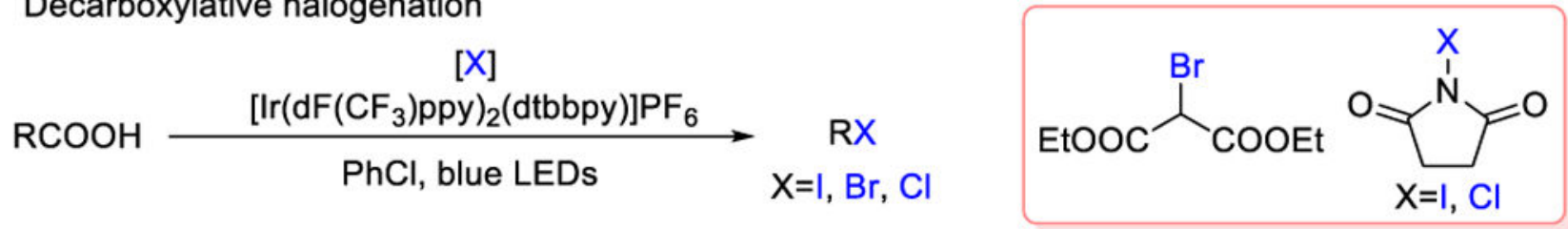

c) Siteselective aliphatic $\mathrm{C}-\mathrm{H}$ halogenation

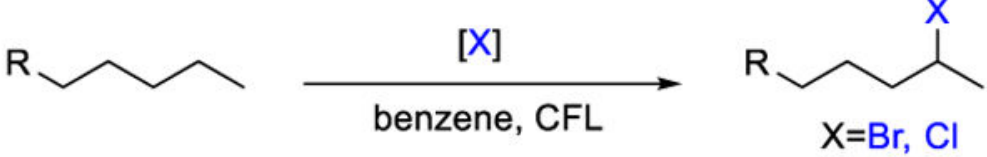<smiles>[X]N(C(=O)c1ccccc1)C(=O)c1cc(C(F)(F)F)cc(C(F)(F)F)c1</smiles>

d) Sulfamate ester directed aliphatic $\mathrm{C}-\mathrm{H}$ chlorination<smiles>[R]NS(=O)(=O)OCCC(Cl)CC</smiles>

this work: deformylative halogenation
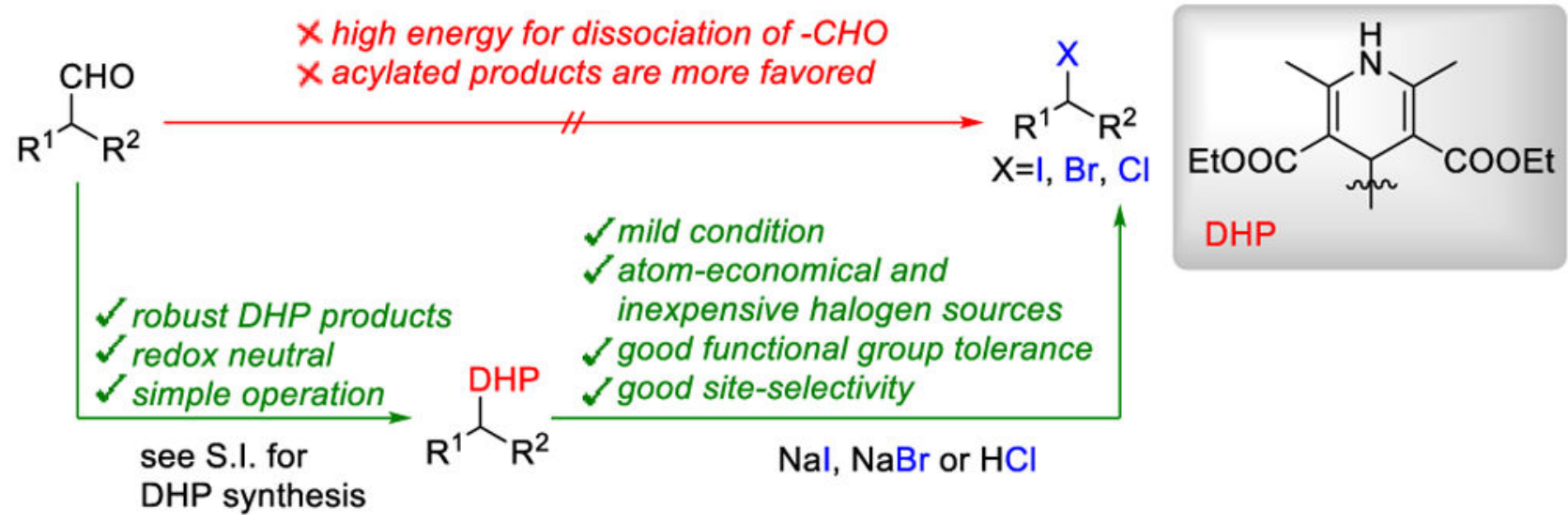

Scheme 1.

Major Photoinduced Synthetic Methods for Alkyl Halides 


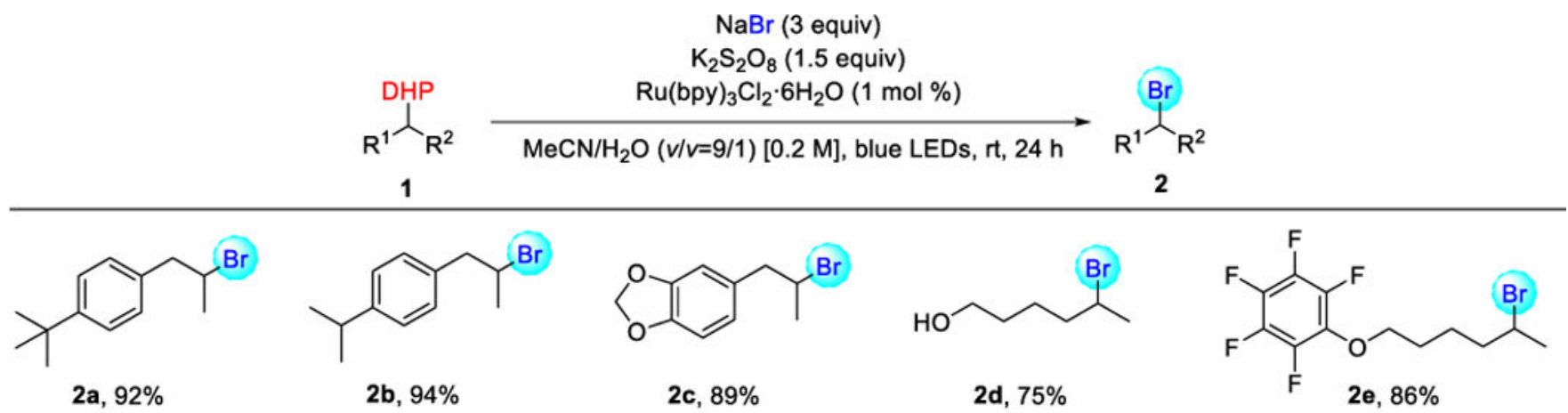<smiles>C[C](Br)CCCCOc1cccc2ccccc12</smiles>

2f, $77 \%$<smiles>CC(Br)CCCCOc1ccc2c(c1)OCC2=O</smiles>

2g, $62 \%$<smiles>CC(Br)CCCCOc1ccc(C#N)cc1</smiles>

$2 \mathrm{~h}, 75 \%$<smiles>[B]C(C)CCCCOc1ccc(C=O)cc1OC</smiles>

$2 \mathbf{i}, 85 \%$<smiles>COc1ccc(C(=O)OCCCCC(C)(Br)c2ccccc2)cc1</smiles>

$2 j, 84 \%$

$2 k, 88 \%$

$21,78 \%$

$2 \mathrm{~m}, 94 \%$<smiles>C[C](Br)CCCCOC(=O)c1ccc(Br)o1</smiles>

2n, $92 \%$<smiles>C[C](Br)CCCCOC(=O)Cc1cccs1</smiles>

2o, $74 \%$<smiles>CC(Br)CCCCOC(=O)c1cscn1</smiles>

$2 p, 84 \%$<smiles>CC(Br)CCCCn1nnc2ccccc21</smiles>

2q, $82 \%$<smiles>CC(=O)c1cn(CCCCC(C)Br)c2ccccc12</smiles><smiles>CCCCCCC(C)(C)OC(=O)O</smiles><smiles>[13CH2]Cc1ccccc1</smiles>

2t, $83 \%$<smiles>Cc1ccc(CBr)cc1</smiles>

$2 u, 82 \%$<smiles>Clc1ccc(CBr)cc1</smiles>

2v, $91 \%$<smiles>[B]Cc1ccccc1C(F)(F)Br</smiles>

$2 \mathrm{x}, 62 \%$

Scheme 2.

Scope of Deformylative Bromination ${ }^{a}$ 


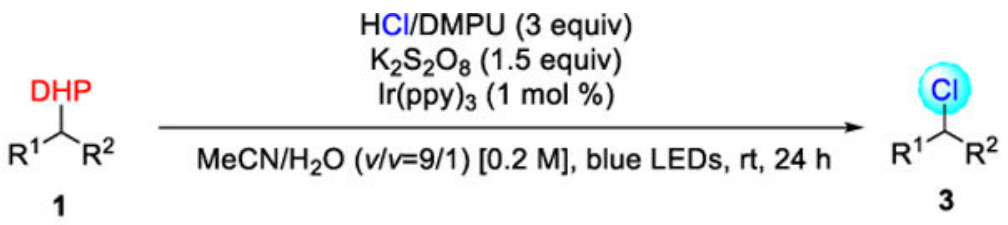<smiles>CC(Cl)Cc1ccc(C(C)(C)C)cc1</smiles>

3a, $80 \%$<smiles>CC(C)c1ccc(CC(C)(C)C)cc1</smiles>

3b, $85 \%$<smiles>CC(Cl)Cc1ccc2c(c1)OCO2</smiles>

$3 c, 82 \%$<smiles>CC(Cl)CCCCO</smiles>

3d, $78 \%$<smiles>CC(Cl)CCCCOC1CCCCO1</smiles><smiles>CC(C)CCCCOc1c(F)c(F)c(F)c(F)c1F</smiles>

3f, $69 \%$<smiles>CC(Cl)CCCCOc1cccc2ccccc12</smiles><smiles>CC(Cl)CCCCOc1ccccc1-c1ccccc1</smiles><smiles>Cc1cc(OCCCCC(C)[Si])cc(=O)o1</smiles>

NC<smiles>CC(Cl)CCCCOc1ccc(F)cc1</smiles>

$\mathrm{OHC}$<smiles>COc1cc(I)ccc1OCCCCC(C)C</smiles><smiles>CC(Cl)CCCCSc1ccc([N+](=O)[O-])cc1</smiles>

$3 \mathbf{i}, 74 \%$

3j, $89 \%$

3k, $83 \%$

3I, $71 \%$<smiles>CC(C)CCCCN1C(=O)c2ccccc2C1=O</smiles><smiles>CC(Cl)CCCCOC(=O)c1ccccc1</smiles>

3n, $80 \%$<smiles>COc1ccc(C(=O)OCCCCC(C)Cl)cc1</smiles>

3o, $82 \%$<smiles>CC(C)CCCCOC(=O)CCc1ccccc1</smiles>

3p, $85 \%$<smiles>CC(Cl)CCCCOC(=O)c1ccc(Br)o1</smiles>

3q, $79 \%$<smiles>CC(C)CCCCOC(=O)Cc1cccs1</smiles>

$3 r, 77 \%$<smiles>CC(Cl)CCCCOC(=O)c1cscn1</smiles>

3s, $66 \%$<smiles>CC(Cl)CCCCn1nnc2ccccc21</smiles>

3t, $70 \%$

Scheme 3.

Scope of Deformylative Chlorination ${ }^{a}$ 
a) proposed bromination mechanism
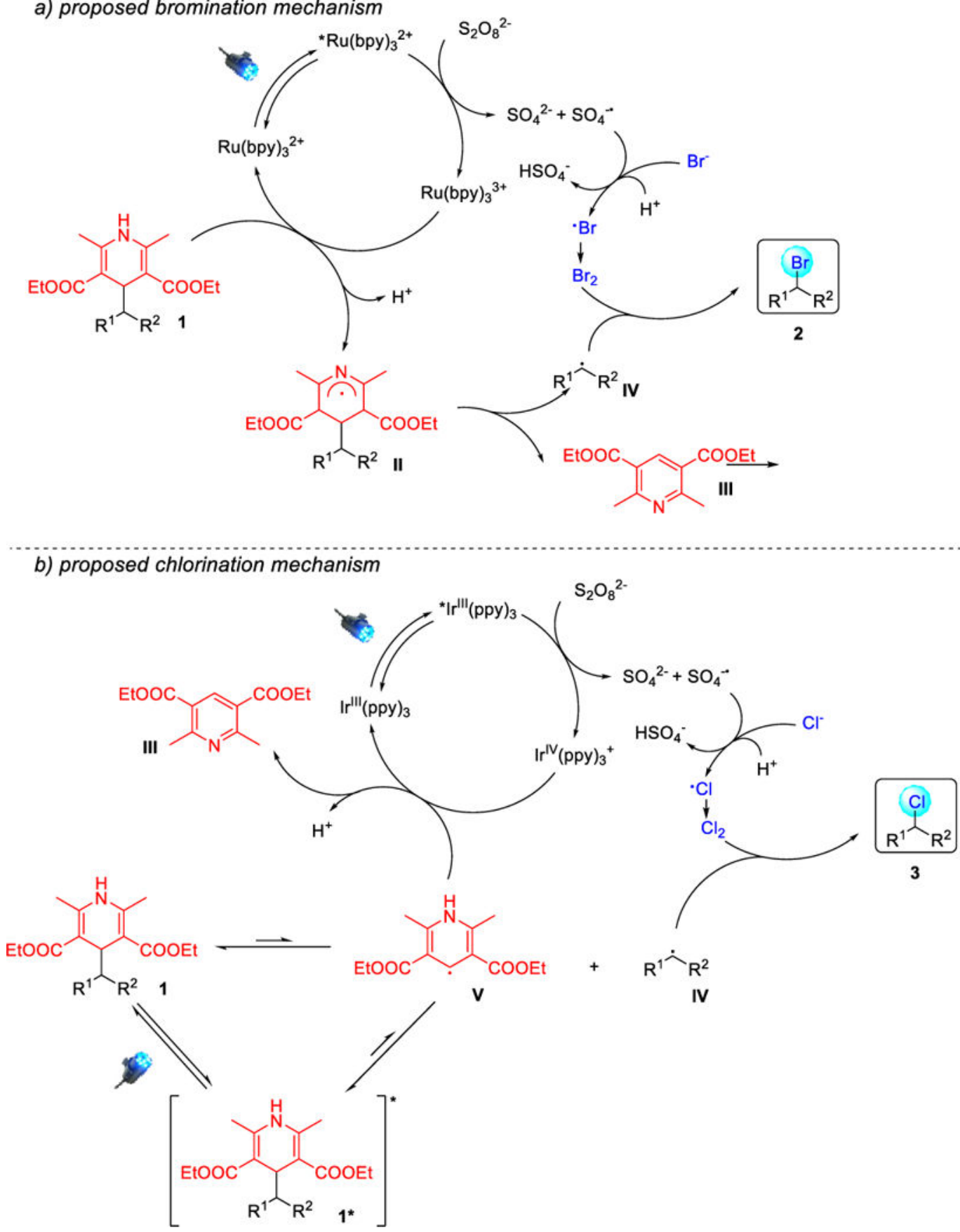

Scheme 4.

Plausible Reaction Mechanism 


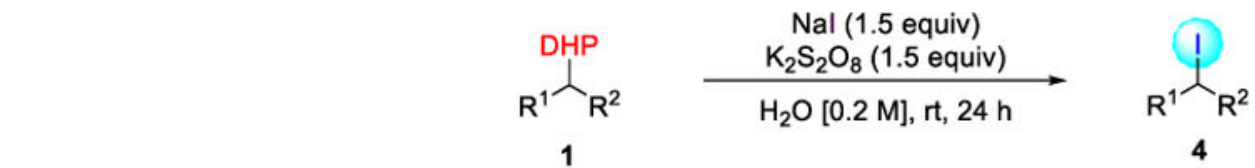

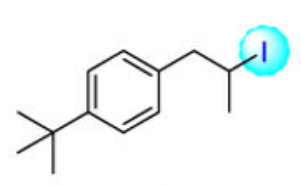

4a, $95 \%$<smiles>CC(C)c1ccc(CC(C)(Cl)Cl)cc1</smiles>

4b, $87 \%$<smiles>CC(C)(C)Cc1ccc2c(c1)OCO2</smiles>

$4 c, 87 \%$<smiles>CC(O)CCCCO</smiles>

4d, $73 \%$

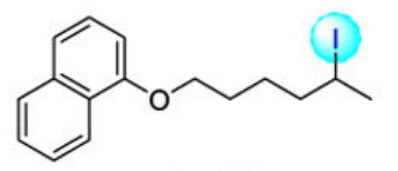

$4 e, 79 \%$<smiles>Cc1ccccc1CCCCOc1ccccc1-c1ccccc1</smiles>

NC<smiles>Cc1ccc(OCCCCC(C)O)cc1</smiles>
4g, $61 \%$<smiles>CC(C)(O)CCCCOc1cccc2cccnc12</smiles>

4h, $93 \%$

$\mathrm{OHC}$<smiles>COc1ccccc1OCCCCc1ccccc1</smiles>

4i, $74 \%$<smiles>CC(O)CCCCOC(=O)c1ccccc1</smiles><smiles>COc1ccc(C(=O)OCCCCC(C)(O)c2ccccc2)cc1</smiles>

4 k, $80 \%$<smiles>CC(C)(O)CCCCOC(=O)c1ccc(Br)o1</smiles>

$4 I, 78 \%$<smiles>CCc1ccc(Cl)cc1</smiles>

$4 m, 45 \%$

Scheme 5.

Scope of Deformylative Iodination ${ }^{a}$ 
Table 1.

Optimization of Visible-Light-Mediated Deformylative Bromination of $1 \mathrm{a}^{a}$

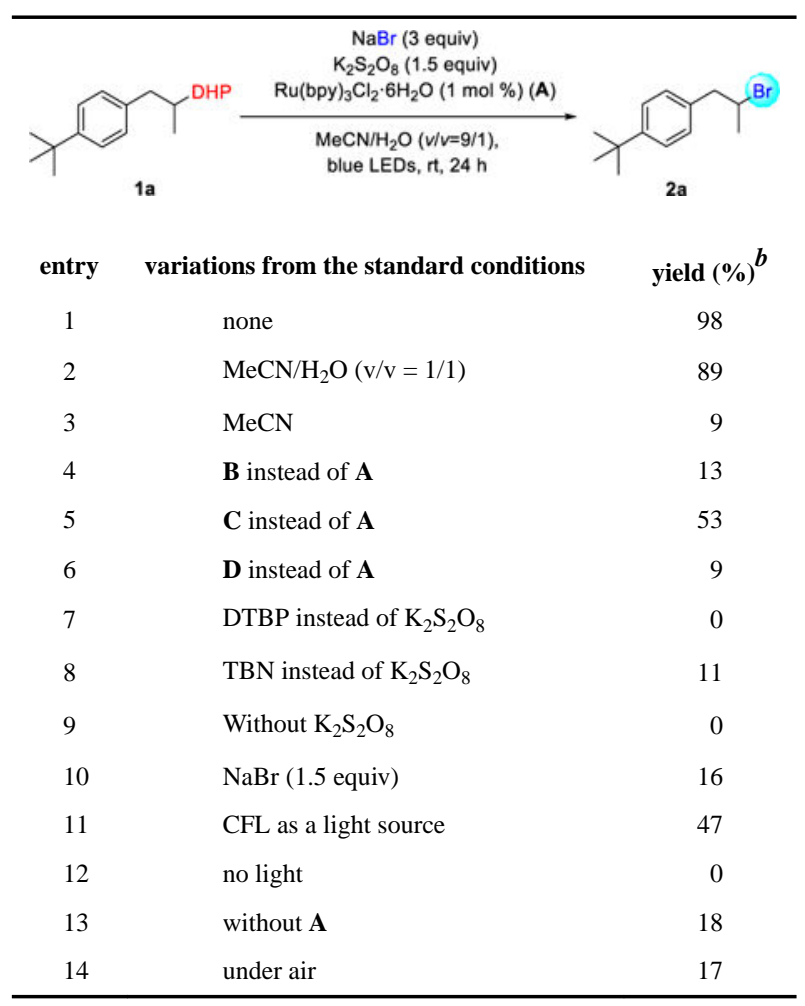

${ }^{a}$ Reaction conditions: $1 \mathrm{a}(0.1 \mathrm{mmol}), \mathrm{NaBr}(0.3 \mathrm{mmol}), \mathrm{K}_{2} \mathrm{~S}_{2} \mathrm{O}_{8}(0.15 \mathrm{mmol}), \mathbf{A}(1 \mathrm{~mol} \%), \mathrm{MeCN} / \mathrm{H}_{2} \mathrm{O}(\mathrm{v} / \mathrm{v}=9 / 1)[0.2 \mathrm{M}]$, blue LEDs, rt, $24 \mathrm{~h}$, Ar atmosphere.

$b_{\text {Yields were determined by }}{ }^{1} \mathrm{H}$ NMR using 1,3,5-trimethoxybenzene as internal standard. $\mathbf{A}=\mathrm{Ru}(\text { bpy })_{3} \mathrm{Cl}_{2} \cdot 6 \mathrm{H}_{2} \mathrm{O}, \mathbf{B}=\operatorname{Ir}(\mathrm{ppy}) 3, \mathbf{C}=\mathrm{Eosin} \mathrm{Y}$ (Green LEDs), D = 9-Mesityl-10-methylacridinium perchlorate, DTBP = Di-tert-butyl peroxide, TBN = tert-butyl nitrite. 
Table 2.

Screening of Chlorine Source and Photocatalyst for Deformylative Chlorination of $1 \mathrm{a}^{a}$

\begin{tabular}{|c|c|c|c|c|}
\hline \multicolumn{5}{|c|}{$\begin{array}{c}{[\mathrm{Cl}] \text { (3 equiv) }} \\
\mathrm{K}_{2} \mathrm{~S}_{2} \mathrm{O}_{8}(1.5 \text { equiv) } \\
\mathrm{PC}(1 \mathrm{~mol} \%)\end{array}$} \\
\hline & 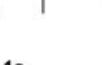 & \multicolumn{2}{|c|}{$\begin{array}{c}\mathrm{MeCN} / \mathrm{H}_{2} \mathrm{O}(\mathrm{v} / \mathrm{v}=9 / 1) \\
\text { blue LEDs, } \mathrm{rt}, 24 \mathrm{~h}\end{array}$} & \\
\hline entry & & {$[\mathrm{Cl}]$} & photocatalyst & yield $(\%)^{b}$ \\
\hline 1 & $\mathrm{LiCl}$ & & A & 37 \\
\hline 2 & $\mathrm{NaCl}$ & & A & 31 \\
\hline 3 & $\mathrm{KCl}$ & & A & 16 \\
\hline 4 & $\mathrm{CsCl}$ & & A & 22 \\
\hline 5 & $\mathrm{NH}_{4} \mathrm{Cl}$ & & A & 54 \\
\hline 6 & $\mathrm{CaCl}_{2}$ & & A & 21 \\
\hline 7 & $\mathrm{HCl} / \mathrm{DM}$ & $\mathrm{U}(43 \% \mathrm{w} / \mathrm{w})$ & A & 62 \\
\hline 8 & $\mathrm{HCl} / \mathrm{DM}$ & $\mathrm{U}(43 \% \mathrm{w} / \mathrm{w})$ & B & 84 \\
\hline 9 & $\mathrm{HCl} / \mathrm{DM}$ & $\mathrm{U}(43 \% \mathrm{w} / \mathrm{w})$ & $\mathrm{C}$ & 44 \\
\hline 10 & $\mathrm{HCl} / \mathrm{DM}$ & $\mathrm{U}(43 \% \mathrm{w} / \mathrm{w})$ & B & $47^{c}$ \\
\hline 11 & $\mathrm{HCl} / \mathrm{DM}$ & $\mathrm{U}(43 \% \mathrm{w} / \mathrm{w})$ & B & $18^{d}$ \\
\hline
\end{tabular}

${ }^{a}$ Reaction conditions: as in Table 1 (entry 1).

${ }^{b}$ Yields were determined by ${ }^{1} \mathrm{H}$ NMR using 1,3,5-trimethoxybenzene as an internal standard. DMPU $=N, N^{\prime}$-Dimethylpropyleneurea.

${ }^{c}$ Without $\mathbf{B}$.

$d_{\text {No light. }}$ 